\title{
SZCZYT NATO W WARSZAWIE W LIPCU 2016 ROKU. IMPLIKACJE DLA BEZPIECZEŃSTWA EUROPY ŚRODKOWO-WSCHODNIEJ
}

21 marca 2016 r. w auli Instytutu Nauk Politycznych i Spraw Międzynarodowych Katolickiego Uniwersytetu Lubelskiego Jana Pawła II odbyło się seminarium naukowe pt. „Szczyt NATO w Warszawie w lipcu 2016 roku. Implikacje dla bezpieczeństwa Europy Środkowo-Wschodniej”. W zorganizowaniu seminarium wzięły udział: Instytut Nauk Politycznych i Spraw Międzynarodowych KUL, Fundacja Konrada Adenauera w Polsce oraz Fundacja Rozwoju KUL. Prelegenci reprezentowali różne instytucje akademickie, polskie i zagraniczne: Katolicki Uniwersytet Lubelski Jana Pawła II, Uniwersytet Marii Curie-Skłodowskiej w Lublinie, Centrum Badań Politycznych Uniwersytetu Iwana Franki we Lwowie.

Uczestnicy seminarium dyskutowali o szczycie NATO, który miał odbyć się w Warszawie 8-9 lipca 2016 r., i jego potencjalnych konsekwencjach dla państw Europy Środkowo-Wschodniej. Szczyt przebiegał w kontekście jakościowych zmian środowiska międzynarodowego - zarówno na południowej, jak i wschodniej flance Sojuszu. Co więcej, z punktu widzenia polityki NATO w regionie Europy Środkowo-Wschodniej rok 2016 może okazać się kluczowy. Związane jest to ze zmianą nie tylko postrzegania sytuacji bezpieczeństwa przez państwa członkowskie NATO, ale również ze zmianami zachodzącymi w sferze środowiska międzynarodowego i zagrożeń dla państw należących do NATO. Przyjęcie Polski do tej struktury w 1999 r. spowodowało przezwyciężenie podziałów w Europie. Szczyt w Warszawie symbolizuje zmiany, jakie zaszły na kontynencie europejskim, ale również potwierdza znaczenie Polski na mapie bezpieczeństwa Sojuszu. Ponadto, na poprzednim spotkaniu NATO w Newport w 2014 r. zapadły decyzje o zwiększeniu jego zdolności do zapobiegania pojawiającym się zagrożeniom. Teraz na szczycie w Warszawie miały zapaść decyzje w tej sprawie, czyli miało dojść do realizacji Readiness Action Plan (zapobieganie pojawiającym się zagrożeniom) oraz wzmocnienia Sił Odpowiedzi, w tym w zakresie stworzenia 
jednostek natychmiastowego reagowania. Tym samym będzie to potwierdzenie adaptacji strategicznej NATO do nowych wyzwań i zagrożeń.

W czasie seminarium szczególny nacisk położono na sytuację Ukrainy (Krym, Donbas) i asertywną politykę Rosji wobec państw Europy Wschodniej oraz państw członkowskich NATO i Unii Europejskiej. Wskazano również na wyzwania i zagrożenia związane z obszarem poradzieckim. Nie ulega wątpliwości, że wojna hybrydowa Rosji z Ukrainą (Zachodem) stanowi wyzwanie dla polityki bezpieczeństwa NATO. Ponadto, aneksja Krymu, dokonana przez Rosję w 2014 r., spowodowała pogwałcenie wielu zasad prawa międzynarodowego publicznego, chociażby Karty Narodów Zjednoczonych (rozdz. I, VI i VII, dotyczące integralności terytorialnej, suwerenności). Warto podkreślić, że przez włączenie do swego terytorium Krymu Rosja stworzyła niebezpieczny precedens dla porządku międzynarodowego. Po raz pierwszy od czasów II wojny światowej doszło w Europie do zajęcia terytorium jednego państwa przez inne z użyciem siły. Dodatkowo, trwająca na wschodzie Ukrainy wojna Rosji z Ukrainą potwierdza, że nastąpiło pogorszenie sytuacji w zakresie bezpieczeństwa na wschodniej flance NATO. Wymusza to na państwach członkowskich i NATO jako organizacji konieczność podejmowania nowych działań na rzecz wzmocnienia bezpieczeństwa i stabilności w Europie Środkowo-Wschodniej.

Wydarzenia, do których doszło w ostatnich latach wewnątrz NATO i Unii Europejskiej, ale też w ich otoczeniu międzynarodowym, nie pozostają bez wpływu na kształt polityki prowadzonej przez nich wobec sąsiadów. Należy wspomnieć o kryzysie w strefie euro, problemie wystąpienia Wielkiej Brytanii z UE („Brexit”), jak również o wojnie w Syrii, kwestii olbrzymiej liczby migrantów w regionie śródziemnomorskim, problemie tzw. Państwa Islamskiego, neoimperialnej polityce Rosji (aneksja Krymu i wspieranie przez nią separatystów w południowej i wschodniej części Ukrainy) etc. Wydarzenia te powodują podział państw członkowskich UE (i de facto NATO) według klucza geograficznego na: 1) państwa zainteresowane sprawami związanymi z regionem Morza Śródziemnego (państwa Południa oraz państwa docelowe dla olbrzymiej liczby migrantów: Niemcy, Austria etc.) oraz 2) państwa skupione na sytuacji we wschodnim sąsiedztwie (Polska, szerzej Europa Środkowa, państwa bałtyckie, Szwecja), gdzie wojna Rosji z Ukrainą stwarza wyzwania dla bezpieczeństwa tych państw i całego regionu.

Zbliżający się szczyt NATO w Warszawie może być istotny z punktu widzenia jakościowych zmian w odniesieniu do bezpieczeństwa Europy Środkowo-Wschodniej. Jeśli państwa członkowskie NATO wykażą się zdolnością myślenia strategicznego, wówczas będziemy mogli obserwować zmiany w podejściu NATO do spraw bezpieczeństwa Polski i innych państw Europy Środkowej oraz w zakresie położenia większego nacisku na solidarność państw członkowskich wobec wyzwań i zagrożeń płynących ze wschodu i południa Europy. Z punktu widzenia państw Europy Środkowej korzystne byłoby obowiązywanie zasady ,jeden za wszystkich, wszyscy za jednego”. Wydaje się to niezwykle istotne w kontekście zmian, do jakich dochodzi za wschodnią granicą Polski, które to zmiany wpływają i będą wpływały na bezpieczeństwo nasze i całego regionu. 


\title{
Plan seminarium
}

\author{
Szczyt NATO w Warszawie w lipcu 2016 roku. \\ Implikacje dla bezpieczeństwa Europy Środkowo-Wschodniej
}

\section{Lublin (Katolicki Uniwersytet Lubelski Jana Pawła II, DMMII, Majdanek) 21 marca 2016 roku}

Otwarcie konferencji:

Prof. Stanisław Wójcik (dyrektor Instytutu Nauk Politycznych i Spraw Międzynarodowych KUL)

Prelegenci:

Dr hab. Andrzej Gil, prof. KUL (KUL)

Polska wobec wspótczesnych zagrożeń a zobowiazania i strategia NATO

Dr Jakub Olchowski (Uniwersytet Marii Curie-Skłodowskiej)

NATO, Rosja i dylemat bezpieczenstwa

Dr Yuriy Hajduk (Centrum Badań Politycznych, Uniwersytet Iwana Franki we Lwowie; PWSZ w Chełmie)

Euroatlantyckie sympatie spoteczeństwa ukraińskiego a relacje Ukraina-NATO po Euromajdanie

Dr Andrzej Szabaciuk (KUL)

NATO wobec kryzysu migracyjnego

Dr hab. Tomasz Stępniewski (KUL)

Szczyt NATO w Warszawie - perspektywa pañstw Europy Wschodniej

Organizacja: dr hab. Tomasz Stępniewski (KUL) i dr Andrzej Szabaciuk (KUL) 